Journal of Clinical Investigation

Vol. 41, No. 2, 1962

\title{
REACTIVITY OF RENAL AND SYSTEMIC CIRCULATIONS TO VASOCONSTRICTOR AGENTS IN NORMOTENSIVE AND HYPERTENSIVE SUBJECTS *
}

\author{
By ERVIN A. GOMBOS, $†$ WILLIAM H. HULET, $\ddagger$ PIERRE BOPP,§ WILLIAM \\ GOLDRING, DAVID S. BALDWIN AND HERBERT CHASIS
}

(From the Department of Medicine, New York University School of Medicine and the Third and Fourth (NYU) Medical Divisions, Bellevue Hospital, New York, N. Y.)

(Submitted for publication June 13, 1961 ; accepted August 31, 1961)

It has been suggested that vascular hyper-reactivity is in part responsible for the vasoconstriction in human essential hypertension. This thesis has been examined by comparing the response to vasoconstrictor agents in hypertensive patients with that of normotensive subjects.

Kylin (1), Brems (2), Gordon and Levitt (3), Fatherree and Hines (4), Judson and co-workers $(5,6)$, and Barany and James $(7)$ failed to demonstrate increased sensitivity to epinephrine or norepinephrine as measured by systemic blood pressure response in hypertensive patients. Goldenberg and associates (8) found no increased response to norepinephrine in hypertensive patients at high dosage but the response was somewhat increased at lower dosage. However, increased response of systemic blood pressure to epinephrine and norepinephrine in hypertension was reported by Clough (9), Jensen (10), and Doyle and Black (11).

In evaluating sensitivity of local vascular beds of the extremities to epinephrine by calorimetric or plethysmographic methods, Pickering and Kissin (12) and Prinzmetal and Wilson (13) found no increased response in hypertensive patients. Contrariwise, Mendlowitz and Naftchi (14), Barany and James (7), and Doyle, Fraser and Marshall (15) reported increased reactivity in hypertension; Duff (16) reported no increased sensitivity to epinephrine in "benign hypertension" but increased reactivity in "progressive or malignant hypertension." Greisman (17)

* This study was supported in part by funds from the Joseph Laffan Morse Foundation and the Abraham S. Birsh Fellowship Fund, and United States Public Health Service Grant H-3272, National Heart Institute, Bethesda, Md.

$\dagger$ Research Fellow, New York Heart Association.

$\ddagger$ Research Fellow, American Heart Association.

$\S$ Abraham S. Birsh Fellow. found that the capillary bed of the nailfold of patients with essential hypertension was hyperreactive to infused $l$-norepinephrine. In normotensive subjects several investigators (18-20) have shown that epinephrine and $l$-norepinephrine produce reduction in renal plasma flow without affecting glomerular filtration rate. However, sensitivity of the renal vascular bed to epinephrine and $l$-norepinephrine has not been studied in subjects with essential hypertension.

The relationship of sodium intake to blood pressure levels in hypertensive patients has suggested the possibility that vascular resistance and reactivity may be affected by sodium content of the body or, specifically, the vessel wall. Raab and colleagues (21) observed a weakened or abolished pressor effect of infused epinephrine and $l$-norepinephrine in hypertensive patients on a rice diet. Aleksandrow and co-workers (22), induced salt depletion in hypertensive subjects by administration of chlorothiazide, and also observed reduction of the pressor effect of infused $l$-norepinephrine. Dahl (23), on the other hand, failed to demonstrate a uniform decrease in pressor response to $l$-norepinephrine after sodium depletion accomplished by dietary restriction in hypertensive patients. None of these studies dealing with the effect of sodium depletion on vascular reactivity includes observations on renal hemodynamics.

This paper deals with observations on the vasoconstrictor effect of infused epinephrine and $l$-norepinephrine on the renal and systemic circulations in normotensive and hypertensive subjects during normal sodium intake as well as after a period of dietary sodium restriction. The data demonstrate that renal and systemic arteriolar vasoconstrictor reactivity is equal in normotensive and hypertensive subjects as shown by an equal relative in- 
TABLE I

Effect of l-norepinephrine on renal and systemic hemodynamics in normotensive and hypertensive subjects on regular salt intake*

\begin{tabular}{|c|c|c|c|c|c|c|c|c|}
\hline $\begin{array}{c}\text { Subject } \dagger \\
\text { Age }\end{array}$ & $\begin{array}{c}l \text {-Norepineph- } \\
\text { rine }\end{array}$ & $\begin{array}{c}\text { Urine } \\
\text { volume }\end{array}$ & GFR & RPF & FF & $\mathbf{R} \mathbf{R}$ & $\mathbf{P}_{\mathbf{m}}$ & Pulse \\
\hline$y r s$ & $\underset{1.73 \mathrm{~m}^{2}}{\mu g / \min /}$ & $m l / m i n$ & $m l / m i n$ & $m l / m i n$ & $\%$ & $\begin{array}{l}\text { dynes- } \\
\text { sec-cm }\end{array}$ & $m m \mathrm{Hg}$ & rate/min \\
\hline \multicolumn{9}{|c|}{ Normotensive subjects } \\
\hline $\begin{array}{c}\text { M.S. } \\
39\end{array}$ & $\begin{array}{c}\text { Control } \\
4.9 \\
13.2 \\
21.4 \\
42.4\end{array}$ & $\begin{array}{l}3.70 \\
2.73 \\
4.78 \\
7.61 \\
9.58\end{array}$ & $\begin{array}{l}122 \\
131 \\
122 \\
117 \\
127\end{array}$ & $\begin{array}{l}602 \\
591 \\
490 \\
410 \\
373\end{array}$ & $\begin{array}{l}20.3 \\
22.1 \\
25.1 \\
28.6 \\
34.0\end{array}$ & $\begin{array}{r}5,070 \\
6,100 \\
8,830 \\
12,000 \\
14,500\end{array}$ & $\begin{array}{r}77 \\
91 \\
107 \\
120 \\
131\end{array}$ & $\begin{array}{l}94 \\
80 \\
79 \\
75 \\
77\end{array}$ \\
\hline O.V. & $\begin{array}{c}\text { Control } \\
2.6 \\
6.6 \\
12.3 \\
20.0\end{array}$ & $\begin{array}{l}0.92 \\
0.85 \\
0.96 \\
0.85 \\
1.08\end{array}$ & $\begin{array}{l}118 \\
105 \\
121 \\
118 \\
130\end{array}$ & $\begin{array}{l}621 \\
507 \\
512 \\
430 \\
407\end{array}$ & $\begin{array}{l}19.1 \\
20.8 \\
23.7 \\
27.5 \\
32.0\end{array}$ & $\begin{array}{r}4,810 \\
6,170 \\
6,500 \\
8,350 \\
10,200\end{array}$ & $\begin{array}{r}88 \\
92 \\
97 \\
104 \\
116\end{array}$ & $\begin{array}{l}74 \\
76 \\
68 \\
66 \\
63\end{array}$ \\
\hline$\underset{45}{\text { M.So. }}$ & $\begin{array}{c}\text { Control } \\
3.0 \\
4.6 \\
7.5 \\
13.9\end{array}$ & $\begin{array}{l}1.95 \\
2.04 \\
2.37 \\
2.34 \\
1.42\end{array}$ & $\begin{array}{l}118 \\
120 \\
127 \\
126 \\
104\end{array}$ & $\begin{array}{l}604 \\
571 \\
505 \\
483 \\
409\end{array}$ & $\begin{array}{l}19.5 \\
21.0 \\
25.1 \\
26.0 \\
25.9\end{array}$ & $\begin{array}{r}5,560 \\
6,810 \\
8,870 \\
9,880 \\
12,400\end{array}$ & $\begin{array}{r}79 \\
90 \\
102 \\
108 \\
114\end{array}$ & $\begin{array}{l}92 \\
96 \\
90 \\
88 \\
78\end{array}$ \\
\hline A.B. & $\begin{array}{c}\text { Control } \\
4.6 \\
7.6 \\
13.9 \\
22.8\end{array}$ & $\begin{array}{c}5.57 \\
9.16 \\
10.2 \\
4.43 \\
3.95\end{array}$ & $\begin{array}{c}118 \\
121 \\
122 \\
105 \\
95.4\end{array}$ & $\begin{array}{l}709 \\
646 \\
582 \\
449 \\
348\end{array}$ & $\begin{array}{l}16.6 \\
18.7 \\
20.9 \\
23.4 \\
27.4\end{array}$ & $\begin{array}{r}4,520 \\
5,420 \\
6,810 \\
8,940 \\
12,500\end{array}$ & $\begin{array}{r}86 \\
93 \\
104 \\
105 \\
113\end{array}$ & $\begin{array}{r}110 \\
100 \\
72 \\
72 \\
66\end{array}$ \\
\hline$\underset{32}{\text { M.H. }}$ & $\begin{array}{c}\text { Control } \\
8.5 \\
13.8 \\
23.0 \\
30.5\end{array}$ & $\begin{array}{l}1.44 \\
8.18 \\
5.09 \\
3.80 \\
4.07\end{array}$ & $\begin{array}{l}157 \\
152 \\
157 \\
154 \\
147\end{array}$ & $\begin{array}{l}616 \\
530 \\
505 \\
445 \\
435\end{array}$ & $\begin{array}{l}25.6 \\
28.7 \\
31.1 \\
34.6 \\
33.8\end{array}$ & $\begin{array}{r}5,180 \\
9,000 \\
9,900 \\
12,500 \\
14,600\end{array}$ & $\begin{array}{r}83 \\
119 \\
124 \\
137 \\
155\end{array}$ & $\begin{array}{l}80 \\
72 \\
60 \\
56 \\
47\end{array}$ \\
\hline $\begin{array}{r}\text { V.C. } \\
29\end{array}$ & $\begin{array}{c}\text { Control } \\
6.6 \\
12.1 \\
19.1 \\
22.6 \\
30.1\end{array}$ & $\begin{array}{l}0.54 \\
0.57 \\
0.76 \\
1.99 \\
5.43 \\
9.15\end{array}$ & $\begin{array}{l}133 \\
132 \\
129 \\
118 \\
121 \\
131\end{array}$ & $\begin{array}{l}773 \\
610 \\
530 \\
460 \\
435 \\
447\end{array}$ & $\begin{array}{l}16.8 \\
21.7 \\
24.3 \\
25.7 \\
27.8 \\
29.3\end{array}$ & $\begin{array}{r}3,910 \\
5,810 \\
7,850 \\
8,660 \\
11,000 \\
13,500\end{array}$ & $\begin{array}{r}79 \\
91 \\
105 \\
\\
120 \\
148\end{array}$ & $\begin{array}{l}80 \\
74 \\
70 \\
75 \\
68 \\
70\end{array}$ \\
\hline G.S. & $\begin{array}{c}\text { Control } \\
13.6 \\
21.8 \\
31.5 \\
36.5\end{array}$ & $\begin{array}{l}0.96 \\
1.52 \\
4.54 \\
5.54 \\
5.51\end{array}$ & $\begin{array}{l}147 \\
141 \\
143 \\
119 \\
113\end{array}$ & $\begin{array}{l}888 \\
641 \\
521 \\
403 \\
355\end{array}$ & $\begin{array}{l}16.6 \\
22.0 \\
27.5 \\
29.5 \\
31.9\end{array}$ & $\begin{array}{r}4,120 \\
7,430 \\
10,200 \\
14,350 \\
16,900\end{array}$ & $\begin{array}{r}93 \\
119 \\
131 \\
142 \\
147\end{array}$ & $\begin{array}{l}78 \\
66 \\
56 \\
52 \\
50\end{array}$ \\
\hline D.J. & $\begin{array}{c}\text { Control } \\
8.0 \\
14.9 \\
24.0 \\
34.5 \\
40.5\end{array}$ & $\begin{array}{l}1.45 \\
4.53 \\
6.99 \\
8.33 \\
7.69 \\
7.48\end{array}$ & $\begin{array}{r}134 \\
.139 \\
130 \\
128 \\
129 \\
136\end{array}$ & $\begin{array}{l}739 \\
636 \\
506 \\
464 \\
426 \\
425\end{array}$ & $\begin{array}{l}18.1 \\
22.2 \\
25.7 \\
27.6 \\
30.3 \\
32.0\end{array}$ & $\begin{array}{r}4,220 \\
5,650 \\
8,060 \\
10,300 \\
11,200 \\
12,000\end{array}$ & $\begin{array}{r}81 \\
92 \\
103 \\
119 \\
119 \\
126\end{array}$ & $\begin{array}{l}64 \\
62 \\
61 \\
60 \\
59 \\
58\end{array}$ \\
\hline$\underset{31}{\text { H.H. }}$ & $\begin{array}{c}\text { Control } \\
8.8 \\
16.5\end{array}$ & $\begin{array}{l}7.45 \\
7.54\end{array}$ & $\begin{array}{l}150 \\
141 \\
136\end{array}$ & $\begin{array}{l}641 \\
511 \\
410\end{array}$ & $\begin{array}{l}23.5 \\
27.6 \\
33.2\end{array}$ & $\begin{array}{r}5,530 \\
8,400 \\
13,900\end{array}$ & $\begin{array}{r}91 \\
108 \\
140\end{array}$ & $\begin{array}{l}81 \\
67 \\
51\end{array}$ \\
\hline M.J. & $\begin{array}{c}\text { Control } \\
4.9 \\
11.2\end{array}$ & $\begin{array}{l}0.58 \\
0.66 \\
0.97\end{array}$ & $\begin{array}{l}134 \\
140 \\
135\end{array}$ & $\begin{array}{l}719 \\
623 \\
596\end{array}$ & $\begin{array}{l}18.6 \\
22.4 \\
22.6\end{array}$ & $\begin{array}{l}6,800 \\
8,610 \\
9,840\end{array}$ & $\begin{array}{l}107 \\
114 \\
125\end{array}$ & $\begin{array}{l}84 \\
82 \\
79\end{array}$ \\
\hline
\end{tabular}

* Clearance values are corrected to $1.73 \mathrm{~m}^{2}$ body surface area. See Methods section for abbreviations. $\dagger$ All subjects are females. 
TABLE I-(Continued)

\begin{tabular}{|c|c|c|c|c|c|c|c|c|}
\hline $\begin{array}{c}\text { Subject } \\
\text { Age }\end{array}$ & $\begin{array}{l}l \text {-Norepineph- } \\
\text { rine }\end{array}$ & $\begin{array}{c}\text { Urine } \\
\text { volume }\end{array}$ & GFR & RPF & FF & $\mathbf{R R}$ & $P_{m}$ & Pulse \\
\hline yrs & $\underset{1.73 \mathrm{~m}^{2}}{\mu g / \min /}$ & $m l / \min$ & $\operatorname{ml} / \min$ & $m l / \min$ & $\%$ & $\begin{array}{l}\text { dynes- } \\
\text { sec-cm-5 }\end{array}$ & $m m H g$ & rate/min \\
\hline $\begin{array}{r}\text { S.R. } \\
30\end{array}$ & $\begin{array}{c}\text { Control } \\
6.6 \\
10.9 \\
17.9 \\
23.8 \\
28.6\end{array}$ & $\begin{array}{l}5.11 \\
5.05 \\
6.20 \\
4.92 \\
4.92 \\
6.28\end{array}$ & $\begin{array}{l}132 \\
139 \\
126 \\
116 \\
114 \\
118\end{array}$ & $\begin{array}{l}858 \\
735 \\
554 \\
431 \\
400 \\
431\end{array}$ & $\begin{array}{l}15.4 \\
18.9 \\
22.7 \\
26.9 \\
28.5 \\
27.4\end{array}$ & $\begin{array}{r}3,790 \\
5,020 \\
7,450 \\
9,800 \\
11,300 \\
11,200\end{array}$ & $\begin{array}{r}84 \\
94 \\
104 \\
107 \\
113 \\
120\end{array}$ & $\begin{array}{l}83 \\
77 \\
73 \\
64 \\
61 \\
60\end{array}$ \\
\hline $\begin{array}{c}\text { D.L. } \\
29\end{array}$ & $\begin{array}{c}\text { Control } \\
6.9 \\
14.6 \\
20.9 \\
24.4 \\
41.8\end{array}$ & $\begin{array}{l}3.70 \\
3.62 \\
7.65 \\
5.21 \\
2.79 \\
5.36\end{array}$ & $\begin{array}{l}121 \\
120 \\
120 \\
101 \\
122 \\
116\end{array}$ & $\begin{array}{l}619 \\
521 \\
431 \\
332 \\
362 \\
345\end{array}$ & $\begin{array}{l}19.7 \\
23.0 \\
27.9 \\
30.4 \\
33.7 \\
33.6\end{array}$ & $\begin{array}{r}4,540 \\
6,470 \\
8,850 \\
11,900 \\
11,800 \\
13,200\end{array}$ & $\begin{array}{r}74 \\
87 \\
97 \\
100 \\
107 \\
114\end{array}$ & $\begin{array}{l}85 \\
74 \\
68 \\
60 \\
60 \\
60\end{array}$ \\
\hline $\begin{array}{c}\text { H.V. } \\
42\end{array}$ & $\begin{array}{c}\text { Control } \\
4.8 \\
9.6\end{array}$ & $\begin{array}{l}2.29 \\
3.10 \\
8.60\end{array}$ & $\begin{array}{l}145 \\
150 \\
159\end{array}$ & $\begin{array}{l}809 \\
687 \\
625\end{array}$ & $\begin{array}{l}18.0 \\
21.9 \\
25.4\end{array}$ & $\begin{array}{l}4,980 \\
7,880 \\
9,750\end{array}$ & $\begin{array}{l}102 \\
133 \\
149\end{array}$ & $\begin{array}{l}83 \\
60 \\
58\end{array}$ \\
\hline \multicolumn{9}{|c|}{ Hypertensive patients } \\
\hline T.B. & $\begin{array}{c}\text { Control } \\
3.1 \\
9.2\end{array}$ & $\begin{array}{l}1.37 \\
6.66 \\
9.26\end{array}$ & $\begin{array}{l}132 \\
122 \\
122\end{array}$ & $\begin{array}{l}474 \\
427 \\
413\end{array}$ & $\begin{array}{l}27.8 \\
28.5 \\
29.5\end{array}$ & $\begin{array}{l}12,700 \\
14,620 \\
16,870\end{array}$ & $\begin{array}{l}147 \\
159 \\
169\end{array}$ & $\begin{array}{l}80 \\
72 \\
72\end{array}$ \\
\hline $\begin{array}{r}\text { L.C. } \\
31\end{array}$ & $\begin{array}{c}\text { Control } \\
1.4 \\
3.0 \\
7.4\end{array}$ & $\begin{array}{l}1.24 \\
1.38 \\
1.25 \\
1.12\end{array}$ & $\begin{array}{l}94.5 \\
97.5 \\
94.6 \\
92.7\end{array}$ & $\begin{array}{l}583 \\
563 \\
521 \\
486\end{array}$ & $\begin{array}{l}16.2 \\
17.3 \\
18.2 \\
20.8\end{array}$ & $\begin{array}{r}7,600 \\
8,400 \\
9,500 \\
11,800\end{array}$ & $\begin{array}{l}111 \\
118 \\
123 \\
130\end{array}$ & $\begin{array}{l}96 \\
96 \\
88 \\
66\end{array}$ \\
\hline $\begin{array}{r}\text { I.F. } \\
49\end{array}$ & $\begin{array}{c}\text { Control } \\
3.6 \\
5.9 \\
11.1 \\
18.1\end{array}$ & $\begin{array}{c}0.96 \\
1.67 \\
2.84 \\
5.92 \\
11.5\end{array}$ & $\begin{array}{l}87.9 \\
100 \\
111 \\
115 \\
114\end{array}$ & $\begin{array}{l}463 \\
456 \\
459 \\
395 \\
356\end{array}$ & $\begin{array}{l}19.0 \\
22.0 \\
24.3 \\
25.4 \\
32.2\end{array}$ & $\begin{array}{l}10,000 \\
12,300 \\
13,200 \\
13,400 \\
20,700\end{array}$ & $\begin{array}{l}114 \\
135 \\
146 \\
166 \\
175\end{array}$ & $\begin{array}{l}84 \\
85 \\
80 \\
74 \\
88\end{array}$ \\
\hline $\begin{array}{c}\text { E.H. } \\
42\end{array}$ & $\begin{array}{c}\text { Control } \\
1.6 \\
2.5 \\
4.8 \\
8.4\end{array}$ & $\begin{array}{l}4.93 \\
8.60 \\
7.96 \\
7.52 \\
4.88\end{array}$ & $\begin{array}{l}129 \\
138 \\
128 \\
127 \\
132\end{array}$ & $\begin{array}{l}567 \\
555 \\
493 \\
457 \\
457\end{array}$ & $\begin{array}{l}22.8 \\
24.8 \\
26.0 \\
27.8 \\
29.0\end{array}$ & $\begin{array}{r}7,650 \\
8,130 \\
9,340 \\
11,300 \\
12,100\end{array}$ & $\begin{array}{l}109 \\
113 \\
115 \\
128 \\
136\end{array}$ & $\begin{array}{l}80 \\
78 \\
64 \\
57 \\
52\end{array}$ \\
\hline$\underset{43}{\text { C. }}$ & $\begin{array}{c}\text { Control } \\
3.0 \\
4.9 \\
9.1 \\
14.7\end{array}$ & $\begin{array}{l}0.93 \\
0.93 \\
0.92 \\
0.94 \\
1.05\end{array}$ & $\begin{array}{l}121 \\
123 \\
117 \\
121 \\
132\end{array}$ & $\begin{array}{l}508 \\
464 \\
413 \\
408 \\
383\end{array}$ & $\begin{array}{l}23.8 \\
26.6 \\
28.5 \\
29.8 \\
34.4\end{array}$ & $\begin{array}{r}9,260 \\
11,300 \\
13,900 \\
14,000 \\
16,700\end{array}$ & $\begin{array}{l}105 \\
116 \\
126 \\
126 \\
140\end{array}$ & $\begin{array}{l}84 \\
83 \\
80 \\
77 \\
77\end{array}$ \\
\hline$\underset{63}{\text { R.M. }}$ & $\begin{array}{c}\text { Control } \\
5.3 \\
12.2 \\
19.8\end{array}$ & $\begin{array}{l}1.71 \\
2.94 \\
4.43 \\
3.89\end{array}$ & $\begin{array}{c}92.0 \\
103 \\
95.6 \\
77.4\end{array}$ & $\begin{array}{l}399 \\
400 \\
326 \\
244\end{array}$ & $\begin{array}{l}23.1 \\
25.7 \\
29.4 \\
31.6\end{array}$ & $\begin{array}{l}11,900 \\
14,600 \\
20,300 \\
30,900\end{array}$ & $\begin{array}{l}118 \\
133 \\
161 \\
182\end{array}$ & $\begin{array}{l}68 \\
66 \\
72 \\
86\end{array}$ \\
\hline $\begin{array}{c}\text { M.L. } \\
26\end{array}$ & $\begin{array}{c}\text { Control } \\
3.4 \\
8.7 \\
12.1 \\
20.1\end{array}$ & $\begin{array}{l}1.11 \\
1.21 \\
2.45 \\
6.18 \\
6.90\end{array}$ & $\begin{array}{l}115 \\
117 \\
117 \\
119 \\
115\end{array}$ & $\begin{array}{l}531 \\
538 \\
461 \\
423 \\
395\end{array}$ & $\begin{array}{l}21.7 \\
21.7 \\
25.3 \\
28.1 \\
29.1\end{array}$ & $\begin{array}{r}8,500 \\
8,550 \\
11,200 \\
12,800 \\
14,400\end{array}$ & $\begin{array}{l}113 \\
115 \\
128 \\
135 \\
140\end{array}$ & $\begin{array}{l}89 \\
83 \\
70 \\
67 \\
65\end{array}$ \\
\hline
\end{tabular}

crease in both renal resistance and systemic blood pressure in response to the administration of epinephrine and $l$-norepinephrine. Sodium restriction failed to decrease reactivity of the renal or systemic circulations to these constrictor agents.

\section{METHODS}

Observations were made in 16 normotensive subjects without evidence of cardiovascular renal disease and in 16 patients with essential hypertension selected from the wards of the New York University Services of Bellevue Hospital. Hypertensive patients were selected in the 
GOMBOS, HULET, BOPP, GOLDRING, BALDWIN AND CHASIS

TABLE II

Effect of epinephrine on renal and systemic hemodynamics in normotensive and hypertensive subjects on regular salt intake*

\begin{tabular}{|c|c|c|c|c|c|c|c|c|}
\hline $\begin{array}{l}\text { Subject } \dagger \\
\text { Age }\end{array}$ & Epinephrine & $\begin{array}{l}\text { Urine } \\
\text { volume }\end{array}$ & GFR & RPF & FF & $\mathbf{R R}$ & $P_{m}$ & Pulse \\
\hline yrs & $\begin{array}{l}\mu \mathrm{g} / \min / \\
1.73 \mathrm{~m}^{2}\end{array}$ & $\mathrm{ml} / \mathrm{min}$ & $\begin{array}{l}m l / \min \\
\text { Normo }\end{array}$ & $\begin{array}{l}\mathrm{ml} / \mathrm{min} \\
\text { ive sub }\end{array}$ & $\%$ & $\begin{array}{l}\text { dynes- } \\
\text { sec-cm }\end{array}$ & $m m H g$ & rate/min \\
\hline $\begin{array}{c}\text { A.B. } \\
19\end{array}$ & $\begin{array}{c}\text { Control } \\
4.7 \\
7.6 \\
14.0 \\
22.8\end{array}$ & $\begin{array}{l}4.32 \\
3.75 \\
4.92 \\
2.62 \\
4.50\end{array}$ & $\begin{array}{l}104 \\
105 \\
120 \\
124 \\
137\end{array}$ & $\begin{array}{l}655 \\
523 \\
560 \\
494 \\
498\end{array}$ & $\begin{array}{l}15.9 \\
20.0 \\
21.5 \\
25.2 \\
27.6\end{array}$ & $\begin{array}{l}4,880 \\
5,780 \\
5,480 \\
6,660 \\
6,590\end{array}$ & $\begin{array}{l}83 \\
79 \\
80 \\
85 \\
85\end{array}$ & $\begin{array}{l}103 \\
124 \\
130 \\
137 \\
145\end{array}$ \\
\hline $\begin{array}{c}\text { M.So. } \\
45\end{array}$ & $\begin{array}{c}\text { Control } \\
3.0 \\
4.6 \\
7.6 \\
13.9 \\
22.7\end{array}$ & $\begin{array}{l}2.57 \\
3.75 \\
6.55 \\
7.77 \\
5.99 \\
5.92\end{array}$ & $\begin{array}{l}128 \\
133 \\
139 \\
138 \\
129 \\
134\end{array}$ & $\begin{array}{l}531 \\
484 \\
501 \\
422 \\
446 \\
412\end{array}$ & $\begin{array}{l}24.1 \\
27.4 \\
27.8 \\
32.8 \\
28.9 \\
32.6\end{array}$ & $\begin{array}{l}8,000 \\
8,540 \\
8,160 \\
9,690 \\
9,060 \\
9,810\end{array}$ & $\begin{array}{r}102 \\
98 \\
97 \\
97 \\
96 \\
96\end{array}$ & $\begin{array}{l}107 \\
108 \\
108 \\
120 \\
120 \\
126\end{array}$ \\
\hline M.S. & $\begin{array}{c}\text { Control } \\
4.4 \\
7.2 \\
13.1 \\
21.4\end{array}$ & $\begin{array}{l}1.85 \\
1.72 \\
1.74 \\
2.03 \\
4.52\end{array}$ & $\begin{array}{l}119 \\
134 \\
129 \\
129 \\
128\end{array}$ & $\begin{array}{l}708 \\
501 \\
517 \\
505 \\
517\end{array}$ & $\begin{array}{l}16.6 \\
26.9 \\
25.0 \\
25.5 \\
24.7\end{array}$ & $\begin{array}{l}5,540 \\
8,680 \\
8,230 \\
7,960 \\
8,040\end{array}$ & $\begin{array}{r}92 \\
101 \\
99 \\
94 \\
94\end{array}$ & $\begin{array}{r}81 \\
105 \\
104 \\
111 \\
121\end{array}$ \\
\hline B.B. & $\begin{array}{c}\text { Control } \\
2.7 \\
4.1 \\
6.7 \\
12.4\end{array}$ & $\begin{array}{l}1.35 \\
1.03 \\
1.07 \\
0.97 \\
0.96\end{array}$ & $\begin{array}{c}96.8 \\
91.0 \\
100 \\
94.7 \\
101\end{array}$ & $\begin{array}{l}499 \\
421 \\
426 \\
386 \\
378\end{array}$ & $\begin{array}{l}19.4 \\
21.6 \\
23.5 \\
24.5 \\
26.7\end{array}$ & $\begin{array}{l}6,810 \\
7,780 \\
7,590 \\
8,260 \\
8,770\end{array}$ & $\begin{array}{l}89 \\
86 \\
85 \\
84 \\
87\end{array}$ & $\begin{array}{r}92 \\
96 \\
95 \\
97 \\
113\end{array}$ \\
\hline$\underset{30}{M . W}$ & $\begin{array}{c}\text { Control } \\
3.9 \\
6.4 \\
11.7 \\
19.2\end{array}$ & $\begin{array}{l}3.58 \\
2.82 \\
3.05 \\
4.53 \\
3.60\end{array}$ & $\begin{array}{l}152 \\
143 \\
140 \\
162 \\
135\end{array}$ & $\begin{array}{l}688 \\
605 \\
444 \\
497 \\
408\end{array}$ & $\begin{array}{l}22.1 \\
23.6 \\
31.6 \\
32.5 \\
33.1\end{array}$ & $\begin{array}{l}6,560 \\
6,680 \\
7,870 \\
6,660 \\
7,100\end{array}$ & $\begin{array}{r}102 \\
95 \\
82 \\
78 \\
69\end{array}$ & $\begin{array}{r}96 \\
128 \\
129 \\
144 \\
154\end{array}$ \\
\hline \multicolumn{9}{|c|}{ Hypertensive patients } \\
\hline $\begin{array}{c}\text { C. H. } \\
43\end{array}$ & $\begin{array}{c}\text { Control } \\
3.0 \\
4.9 \\
9.0 \\
14.6\end{array}$ & $\begin{array}{l}1.27 \\
1.58 \\
2.50 \\
1.79 \\
1.61\end{array}$ & $\begin{array}{l}114 \\
125 \\
124 \\
117 \\
126\end{array}$ & $\begin{array}{l}478 \\
478 \\
431 \\
391 \\
348\end{array}$ & $\begin{array}{l}23.9 \\
26.4 \\
28.8 \\
29.8 \\
36.2\end{array}$ & $\begin{array}{r}9,380 \\
8,110 \\
9,420 \\
11,000 \\
12,900\end{array}$ & $\begin{array}{r}107 \\
94 \\
98 \\
103 \\
107\end{array}$ & $\begin{array}{r}92 \\
96 \\
102 \\
104 \\
115\end{array}$ \\
\hline$\underset{63}{R . M .}$ & $\begin{array}{c}\text { Control } \\
4.1 \\
12.2 \\
19.9\end{array}$ & $\begin{array}{l}1.42 \\
1.66 \\
0.99 \\
0.68\end{array}$ & $\begin{array}{c}122 \\
108 \\
92.0 \\
93.3\end{array}$ & $\begin{array}{l}589 \\
418 \\
336 \\
294\end{array}$ & $\begin{array}{l}20.6 \\
25.8 \\
27.4 \\
31.8\end{array}$ & $\begin{array}{r}6,450 \\
9,170 \\
10,600 \\
14,900\end{array}$ & $\begin{array}{l}100 \\
101 \\
109 \\
114\end{array}$ & $\begin{array}{r}78 \\
87 \\
123 \\
126\end{array}$ \\
\hline$\underset{54}{\text { L.G. }}$ & $\begin{array}{c}\text { Control } \\
3.5 \\
5.7 \\
10.6 \\
17.2\end{array}$ & $\begin{array}{l}0.65 \\
0.76 \\
0.55 \\
0.51 \\
0.55\end{array}$ & $\begin{array}{l}83.0 \\
98.0 \\
88.3 \\
73.4 \\
83.7\end{array}$ & $\begin{array}{l}420 \\
377 \\
308 \\
280 \\
274\end{array}$ & $\begin{array}{l}19.8 \\
26.0 \\
28.6 \\
27.2 \\
30.6\end{array}$ & $\begin{array}{l}10,300 \\
11,100 \\
13,100 \\
15,800 \\
18,000\end{array}$ & $\begin{array}{l}111 \\
101 \\
104 \\
109 \\
122\end{array}$ & $\begin{array}{r}84 \\
82 \\
84 \\
103 \\
112\end{array}$ \\
\hline $\begin{array}{r}\text { L.C. } \\
42\end{array}$ & $\begin{array}{c}\text { Control } \\
6.2 \\
11.4\end{array}$ & $\begin{array}{l}1.24 \\
1.22 \\
1.09\end{array}$ & $\begin{array}{l}110 \\
110 \\
100\end{array}$ & $\begin{array}{l}568 \\
420 \\
372\end{array}$ & $\begin{array}{l}19.4 \\
26.2 \\
26.9\end{array}$ & $\begin{array}{r}7,770 \\
9,400 \\
12,300\end{array}$ & $\begin{array}{r}107 \\
97 \\
111\end{array}$ & $\begin{array}{r}74 \\
90 \\
105\end{array}$ \\
\hline $\begin{array}{c}\text { N.F. } \\
38\end{array}$ & $\begin{array}{c}\text { Control } \\
1.9 \\
3.9 \\
5.6 \\
9.3\end{array}$ & $\begin{array}{l}3.58 \\
5.70 \\
5.58 \\
3.60 \\
3.02\end{array}$ & $\begin{array}{l}132 \\
142 \\
139 \\
138 \\
120\end{array}$ & $\begin{array}{l}614 \\
601 \\
518 \\
536 \\
387\end{array}$ & $\begin{array}{l}21.5 \\
23.6 \\
26.8 \\
25.8 \\
31.0\end{array}$ & $\begin{array}{r}6,710 \\
6,780 \\
8,210 \\
8,740 \\
13,400\end{array}$ & $\begin{array}{l}104 \\
103 \\
107 \\
117 \\
128\end{array}$ & $\begin{array}{r}82 \\
93 \\
109 \\
122 \\
147\end{array}$ \\
\hline
\end{tabular}

* Clearance values are corrected to $1.73 \mathrm{~m}^{2}$ body surface area. See Methods section for abbreviations. $\uparrow$ Subjects J.B. and J.M. are males. 
REACTIVITY OF VASOCONSTRICTOR AGENTS IN HYPERTENSION

TABLE II-(Continued)

\begin{tabular}{|c|c|c|c|c|c|c|c|c|}
\hline $\begin{array}{l}\text { Subject } \dagger \\
\text { Age }\end{array}$ & Epinephrine & $\begin{array}{l}\text { Urine } \\
\text { volume }\end{array}$ & GFR & $\mathrm{RPF}$ & FF & $\mathbf{R R}$ & $P_{m}$ & Pulse \\
\hline$y r s$ & $\underset{1.73 \mathrm{~m}^{2}}{\mu \mathrm{g} / \mathrm{min} /}$ & $\mathrm{ml} / \mathrm{min}$ & $\operatorname{ml} / \min$ & $\mathrm{ml} / \mathrm{min}$ & $\%$ & $\begin{array}{c}\text { dynes- } \\
\text { sec-cm-s }\end{array}$ & $m m \mathrm{Hg}$ & rate/min \\
\hline$\underset{26}{\text { M.R. }}$ & $\begin{array}{c}\text { Control } \\
5.5 \\
11.5 \\
16.4 \\
21.9 \\
27.4\end{array}$ & $\begin{array}{c}14.4 \\
10.7 \\
6.28 \\
4.71 \\
6.87 \\
8.32\end{array}$ & $\begin{array}{l}135 \\
133 \\
131 \\
126 \\
137 \\
134\end{array}$ & $\begin{array}{l}683 \\
555 \\
490 \\
467 \\
427 \\
411\end{array}$ & $\begin{array}{l}19.7 \\
24.0 \\
26.7 \\
27.0 \\
32.1 \\
32.7\end{array}$ & $\begin{array}{l}6,430 \\
7,430 \\
8,060 \\
8,260 \\
9,150 \\
9,500\end{array}$ & $\begin{array}{r}110 \\
104 \\
100 \\
98 \\
99 \\
99\end{array}$ & $\begin{array}{r}84 \\
92 \\
104 \\
111 \\
116 \\
120\end{array}$ \\
\hline $\begin{array}{r}\text { J.B. } \\
49\end{array}$ & $\begin{array}{c}\text { Control } \\
4.2 \\
10.5 \\
14.7\end{array}$ & $\begin{array}{l}1.02 \\
1.63 \\
2.23 \\
3.13\end{array}$ & $\begin{array}{c}97.3 \\
100 \\
114 \\
81.1\end{array}$ & $\begin{array}{l}582 \\
525 \\
444 \\
287\end{array}$ & $\begin{array}{l}16.7 \\
18.8 \\
25.7 \\
28.3\end{array}$ & $\begin{array}{r}7,010 \\
7,770 \\
8,500 \\
10,400\end{array}$ & $\begin{array}{r}103 \\
103 \\
96 \\
78\end{array}$ & $\begin{array}{r}80 \\
96 \\
108 \\
126\end{array}$ \\
\hline$\underset{37}{\text { J.M. }}$ & $\begin{array}{c}\text { Control } \\
4.4 \\
10.9 \\
15.2 \\
21.8\end{array}$ & $\begin{array}{l}0.58 \\
0.58 \\
0.93 \\
1.64 \\
1.45\end{array}$ & $\begin{array}{l}112 \\
121 \\
120 \\
121 \\
124\end{array}$ & $\begin{array}{l}467 \\
457 \\
388 \\
366 \\
348\end{array}$ & $\begin{array}{l}24.2 \\
26.5 \\
31.0 \\
33.1 \\
35.6\end{array}$ & $\begin{array}{r}8,840 \\
8,170 \\
9,489 \\
10,200 \\
10,500\end{array}$ & $\begin{array}{r}104 \\
95 \\
94 \\
95 \\
93\end{array}$ & $\begin{array}{r}84 \\
95 \\
107 \\
114 \\
124\end{array}$ \\
\hline L.L. & $\begin{array}{c}\text { Control } \\
4.5 \\
11.4 \\
15.9\end{array}$ & $\begin{array}{l}7.39 \\
5.62 \\
5.84 \\
1.70\end{array}$ & $\begin{array}{c}115 \\
106 \\
111 \\
96.9\end{array}$ & $\begin{array}{l}580 \\
455 \\
476 \\
393\end{array}$ & $\begin{array}{l}19.9 \\
23.3 \\
23.3 \\
24.6\end{array}$ & $\begin{array}{r}7,770 \\
9,150 \\
8,650 \\
10,300\end{array}$ & $\begin{array}{l}113 \\
105 \\
104 \\
102\end{array}$ & $\begin{array}{r}84 \\
88 \\
104 \\
110\end{array}$ \\
\hline P.T. & $\begin{array}{c}\text { Control } \\
3.8 \\
9.8 \\
13.5\end{array}$ & $\begin{array}{c}0.89 \\
1.22 \\
5.12 \\
13.0\end{array}$ & $\begin{array}{l}143 \\
143 \\
149 \\
142\end{array}$ & $\begin{array}{l}623 \\
568 \\
538 \\
487\end{array}$ & $\begin{array}{l}23.0 \\
25.2 \\
27.7 \\
29.1\end{array}$ & $\begin{array}{l}6,970 \\
7,180 \\
7,480 \\
8,380\end{array}$ & $\begin{array}{l}109 \\
103 \\
102 \\
103\end{array}$ & $\begin{array}{r}84 \\
99 \\
115 \\
122\end{array}$ \\
\hline
\end{tabular}

early stages of their disease, as judged by the absence of proteinuria and by minimal retinal and cardiac abnormalities.

The effect of $l$-norepinephrine on systemic blood pressure and renal hemodynamics was examined in 13 normotensive and 7 hypertensive subjects, and of epinephrine in 5 normotensive and 10 hypertensive subjects on a regular diet with normal salt content (10 to $15 \mathrm{~g}$ sodium chloride per day). The effect of $l$-norepinephrine during restricted dietary intake of salt $(250 \mathrm{mg}$ sodium chloride per day) was examined in 3 of the normotensive and 3 of the hypertensive subjects and of epinephrine in 4 of the normotensive and 5 of the hypertensive subjects. Adherence to the regimen was verified by measurement of 24-hour urinary sodium excretion rates.

Fluids were withheld for 12 hours preceding the test, which was performed in the morning with the patient in the fasting state. Urine was collected from an indwelling catheter and the bladder was emptied by means of air and without washout. Surgical sterility was maintained throughout the test, and an antibiotic was administered for 5 days following the test.

After the injection of suitable priming doses of inulin and $p$-aminohippurate, a sustaining infusion of these substances dissolved in normal saline was administered at a rate of $2 \mathrm{ml}$ per minute. Urine was collected during one to three periods totalling 30 to 45 minutes for the determination of glomerular filtration rate (GFR) and renal plasma flow (RPF). Thereafter an infusion of $l$-norepinephrine or epinephrine in concentrations of 1.5 $\mu \mathrm{g}$ per $\mathrm{ml}$ in 5 per cent dextrose in distilled water was administered at successively increasing rates, starting at approximately $2.5 \mu \mathrm{g}$ per minute. In most of the normotensive subjects the dosage of $l$-norepinephrine or epinephrine was increased to approximately $30 \mu \mathrm{g}$ per minute, but in hypertensive subjects adverse manifestations such as substernal pressure, throbbing headache, palpitation or cardiac arrhythmia precluded administration of doses much in excess of $10 \mu \mathrm{g}$ per minute. A separate urine collection was made to correspond with each dosage of vasoconstrictor. At appropriate time intervals blood samples were drawn from an antecubital vein, centrifuged immediately, and the plasma stored in stoppered tubes. Systemic blood pressures were recorded every 3 to 5 minutes throughout the study by the auscultatory method and averaged for each period. The mean blood pressure $\left(P_{m}\right)$ was calculated as one-third of pulse pressure plus the diastolic pressure. Renal resistance (RR) was calculated according to the method of Gomez (24). Inulin was determined by a modification of Harrison's method, and $p$-aminohippurate by the method of Smith (25). Urinary sodium concentrations were measured with a flame photometer using lithium as an internal standard.

The observed values for GFR, $R P F, P_{m}$ and $R R$ in each subject were plotted against dosage of vasoconstrictor and the values for doses of $2.5,5.0,7.5$, and 10 $\mu \mathrm{g}$ per minute were then derived for each parameter by interpolation. Mean values for both actual and percentage change were calculated from the interpolated values for the observations made during normal salt intake. Mean values were not calculated for the stud- 


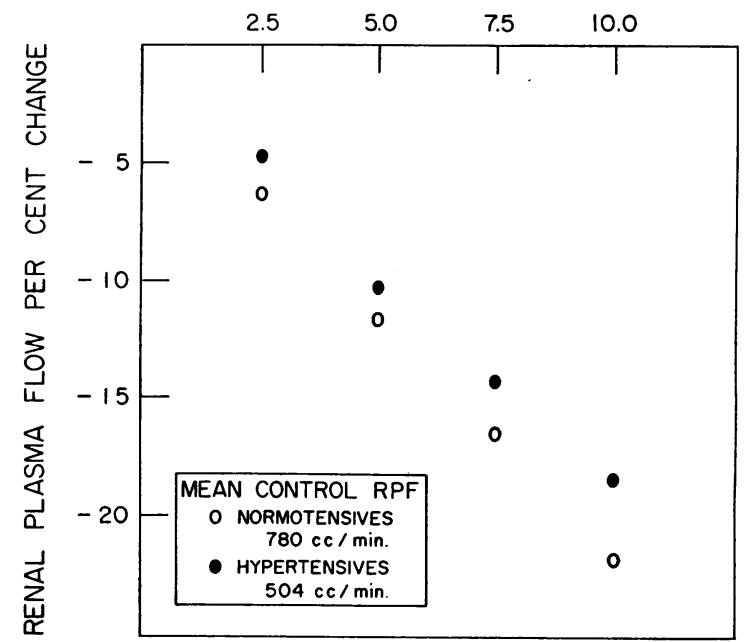

Fig. 1. EFfECT of $l$-NOREPINEPHRINE ON RENAL PLASMA FLow. Each open circle represents the mean value for 13 normotensive subjects and each closed circle the mean for 7 hypertensive subjects.

ies performed during restricted dietary intake of salt because of the small number of subjects.

The observed values for all doses administered are presented in Tables I, II, IV and V. However, for the purpose of comparing the responses in hypertensive and normotensive subjects we have utilized the values inter-

EPINEPHRINE $\mu \mathrm{gm} / \mathrm{min} / 1.73 \mathrm{~m}^{2}$

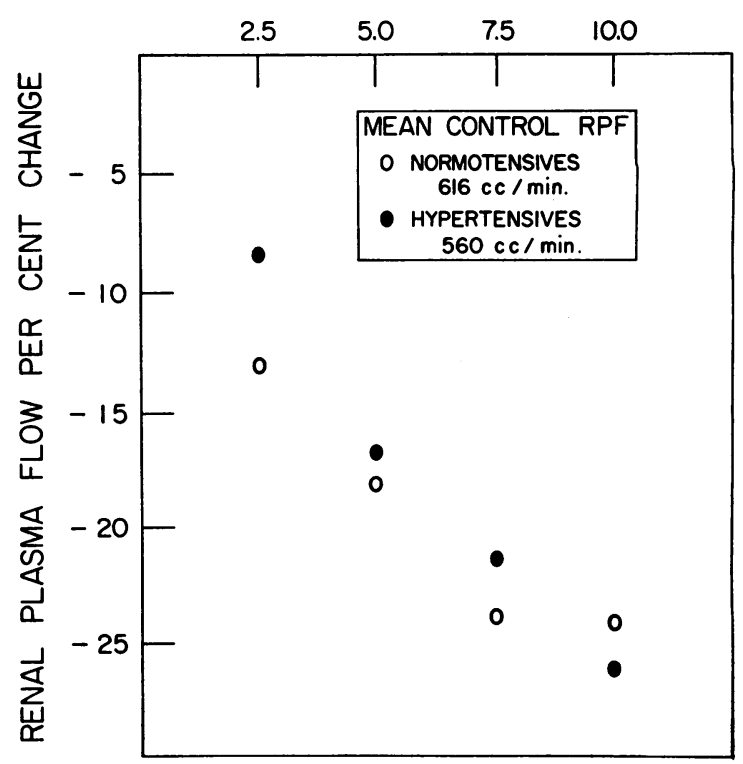

Fig. 2. EFfect of EPINEPHRINE ON RENAL PLASMa FLow. Each open circle represents the mean value for 5 normotensive subjects and each closed circle the mean for 10 hypertensive subjects. 
polated at $10 \mu \mathrm{g}$ per minute (Figures $1-5$ and Tables III, VI and VII) and will refer to these in our results, inasmuch as this is the largest dose at which data are available for comparison in all subjects.

\section{RESULTS}

Regular diet with normal salt content (Tables $I, I I$, and III; Figures 1-5). l-Norepinephrine induced a mean decrease in RPF of $157 \mathrm{ml}$ per minute ( -21.8 per cent) in 13 normotensive subjects and of $95 \mathrm{ml}$ per minute $(-18.1$ per cent) in 7 hypertensive subjects. Epinephrine induced a

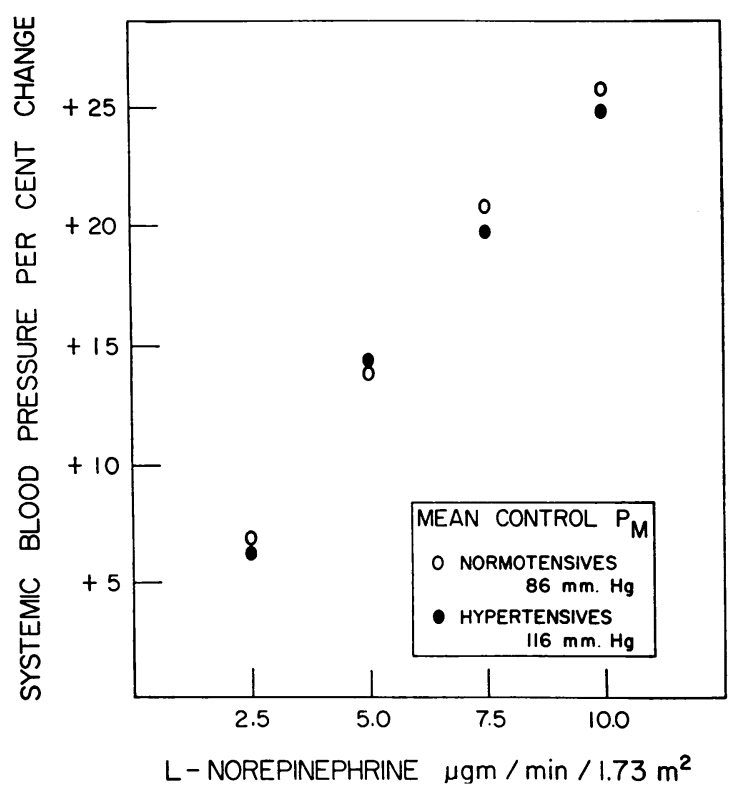

Fig. 3. EFFECT OF $l$-NOREPINEPHRINE ON SYSTEMIC BLOOD PRESSURE. Each open circle represents the mean value for 13 normotensive subjects and each closed circle the mean for 7 hypertensive subjects.

mean decrease in RPF of $149 \mathrm{ml}$ per minute ( -23.8 per cent) in 5 normotensive subjects and of $157 \mathrm{ml}$ per minute $(-26.0$ per cent) in 10 hypertensive subjects.

$l$-Norepinephrine caused comparable increases in $\mathrm{P}_{\mathrm{m}}$ in the two groups, a mean of $22 \mathrm{~mm} \mathrm{Hg}$ $(+25.6$ per cent) in normotensives and $29 \mathrm{~mm}$ $\mathrm{Hg}(+24.7$ per cent) in hypertensives. Epinephrine caused no significant changes in $P_{m}$ in either normotensives or hypertensives, a mean of $-6 \mathrm{~mm} \mathrm{Hg}$ ( -5.7 per cent) in the former and $-2 \mathrm{~mm} \mathrm{Hg}(-1.54$ per cent) in the latter.

$l$-Norepinephrine did not change GFR in either group. Since percentage decrease in RPF was

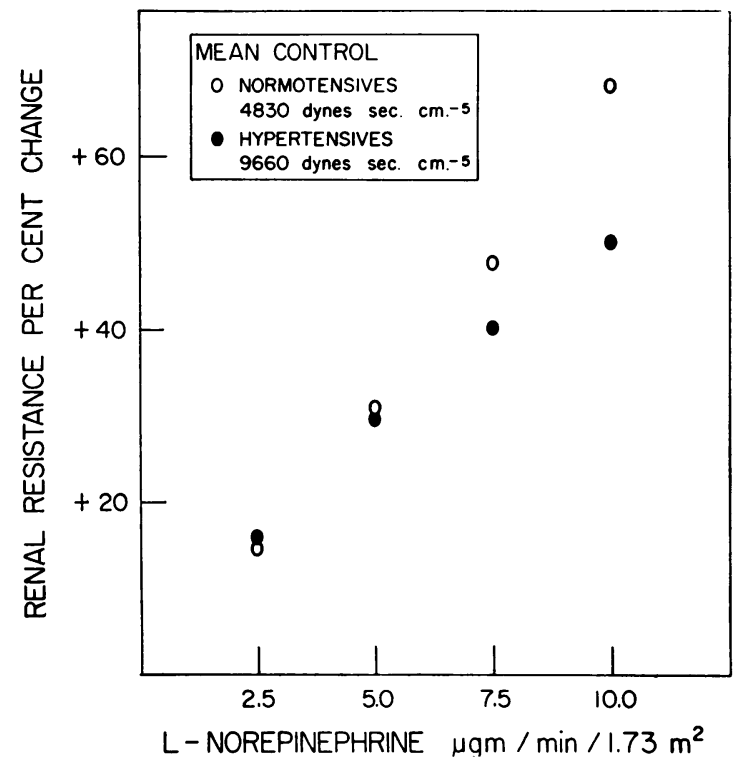

Fig. 4. EFFECT OF $l$-NOREPINEHRINE ON RENAL RESISTANCE. Each open circle represents the mean value for 13 normotensive subjects and each closed circle the mean for 7 hypertensive subjects.

comparable in normotensive and hypertensive subjects, percentage increases in filtration fraction (FF) were also equal, in the former from a mean control value of 0.191 to 0.244 ( +29.2 per cent) and in the latter from 0.221 to $0.273(+33.1$ per cent). Similarly, epinephrine failed to affect GFR, and FF was increased to the same extent in normotensive and hypertensive subjects, from 0.196 to $0.262(+35.1$ per cent $)$ in the former and from 0.209 to $0.276(+32.7$ per cent) in the latter.

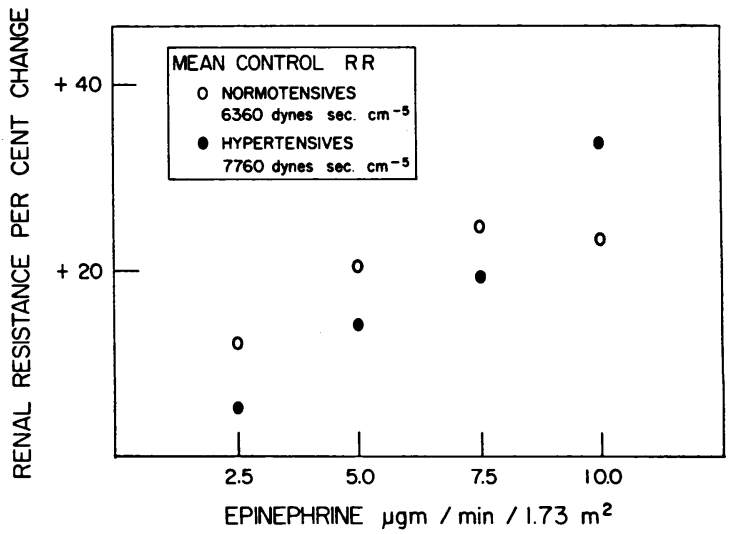

Fig. 5. EFFECT OF EPINEPHRINe ON RENAL RESistance. Each open circle represents the mean value for 5 normotensive subjects and each closed circle the mean for 10 hypertensive subjects. 
TABLE IV

Effect of l-norepinephrine on renal and systemic hemodynamics in normotensive and hypertensive subjects on reduced salt intake*

\begin{tabular}{|c|c|c|c|c|c|c|c|c|}
\hline $\begin{array}{c}\text { Subject } \dagger \\
\text { Age }\end{array}$ & $\begin{array}{l}l \text {-Norepineph- } \\
\text { rine }\end{array}$ & $\begin{array}{l}\text { Urine } \\
\text { volume }\end{array}$ & GFR & RPF & FF & $\mathbf{R R}$ & $P_{m}$ & Pulse \\
\hline yrs & $\underset{1.73 \mathrm{~m}^{2}}{\mu \mathrm{min} /}$ & $m l / \min$ & $\operatorname{ml} / \min$ & $m l / \min$ & $\%$ & $\begin{array}{c}\text { dynes- } \\
{\sec -\mathrm{cm}^{-6}}^{-6}\end{array}$ & $m m H g$ & rate $/ \min$ \\
\hline \multicolumn{9}{|c|}{ Normotensive subjects } \\
\hline $\begin{array}{r}\text { A.B. } \\
19\end{array}$ & $\begin{array}{c}\text { Control } \\
4.7 \\
7.6 \\
14.0 \\
22.8\end{array}$ & $\begin{array}{l}1.51 \\
1.23 \\
1.78 \\
1.10 \\
1.39\end{array}$ & $\begin{array}{c}108 \\
96.3 \\
105 \\
84.1 \\
86.2\end{array}$ & $\begin{array}{l}755 \\
514 \\
481 \\
302 \\
258\end{array}$ & $\begin{array}{l}14.4 \\
18.7 \\
21.9 \\
28.0 \\
33.4\end{array}$ & $\begin{array}{r}4,130 \\
7,530 \\
8,340 \\
14,000 \\
17,700\end{array}$ & $\begin{array}{r}84 \\
102 \\
105 \\
110 \\
118\end{array}$ & $\begin{array}{r}111 \\
73 \\
67 \\
62 \\
61\end{array}$ \\
\hline$\underset{45}{\text { M.So. }}$ & $\begin{array}{c}\text { Control } \\
4.6 \\
7.6 \\
13.9 \\
22.5\end{array}$ & $\begin{array}{l}2.56 \\
2.13 \\
1.98 \\
1.27 \\
0.85\end{array}$ & $\begin{array}{r}118 \\
114 \\
104 \\
89 \\
78\end{array}$ & $\begin{array}{l}694 \\
535 \\
416 \\
324 \\
236\end{array}$ & $\begin{array}{l}17.1 \\
21.3 \\
25.0 \\
27.3 \\
32.9\end{array}$ & $\begin{array}{r}4,990 \\
7,620 \\
10,700 \\
14,900 \\
21,700\end{array}$ & $\begin{array}{r}89 \\
103 \\
112 \\
120 \\
127\end{array}$ & $\begin{array}{r}100 \\
95 \\
92 \\
81 \\
73\end{array}$ \\
\hline $\begin{array}{c}\text { M.S. } \\
39\end{array}$ & $\begin{array}{c}\text { Control } \\
2.9 \\
3.4 \\
7.2 \\
13.1 \\
21.4\end{array}$ & $\begin{array}{l}2.84 \\
0.89 \\
2.63 \\
3.61 \\
5.88 \\
6.25\end{array}$ & $\begin{array}{l}83.6 \\
111 \\
112 \\
124 \\
113 \\
101\end{array}$ & $\begin{array}{l}602 \\
527 \\
465 \\
464 \\
315 \\
314\end{array}$ & $\begin{array}{l}20.1 \\
21.0 \\
24.2 \\
26.8 \\
35.8 \\
32.2\end{array}$ & $\begin{array}{r}4,810 \\
6,090 \\
7,480 \\
8,180 \\
13,600 \\
14,500\end{array}$ & $\begin{array}{r}75 \\
82 \\
88 \\
95 \\
106 \\
112\end{array}$ & $\begin{array}{l}90 \\
76 \\
77 \\
76 \\
74 \\
77\end{array}$ \\
\hline O.V. & $\begin{array}{c}\text { Control } \\
4.1 \\
6.7 \\
12.4 \\
20.0\end{array}$ & $\begin{array}{l}1.15 \\
0.73 \\
0.98 \\
0.61 \\
0.52\end{array}$ & $\begin{array}{l}122 \\
101 \\
107 \\
116 \\
116\end{array}$ & $\begin{array}{l}788 \\
597 \\
588 \\
563 \\
537\end{array}$ & $\begin{array}{l}15.6 \\
16.9 \\
18.2 \\
20.6 \\
21.6\end{array}$ & $\begin{array}{l}3,560 \\
4,760 \\
5,170 \\
5,700 \\
6,500\end{array}$ & $\begin{array}{l}79 \\
80 \\
85 \\
89 \\
96\end{array}$ & $\begin{array}{l}84 \\
74 \\
76 \\
75 \\
67\end{array}$ \\
\hline \multicolumn{9}{|c|}{ Hypertensive patients } \\
\hline $\begin{array}{c}\text { E.H. } \\
42\end{array}$ & $\begin{array}{c}\text { Control } \\
1.2 \\
3.7 \\
11.1\end{array}$ & $\begin{array}{l}0.39 \\
0.40 \\
0.39 \\
0.48\end{array}$ & $\begin{array}{l}96.0 \\
89.4 \\
88.5 \\
96.6\end{array}$ & $\begin{array}{l}382 \\
390 \\
350 \\
299\end{array}$ & $\begin{array}{l}25.1 \\
22.9 \\
25.8 \\
32.4\end{array}$ & $\begin{array}{l}10,300 \\
11,100 \\
15,000 \\
19,900\end{array}$ & $\begin{array}{l}100 \\
109 \\
130 \\
146\end{array}$ & $\begin{array}{l}66 \\
56 \\
58 \\
56\end{array}$ \\
\hline$\underset{31}{\text { L.C. }}$ & $\begin{array}{c}\text { Control } \\
7.4 \\
13.8 \\
22.3\end{array}$ & $\begin{array}{l}1.42 \\
2.44 \\
2.07 \\
1.48\end{array}$ & $\begin{array}{l}66.2 \\
85.8 \\
75.7 \\
93.0\end{array}$ & $\begin{array}{l}420 \\
439 \\
376 \\
339\end{array}$ & $\begin{array}{l}15.8 \\
19.5 \\
20.2 \\
27.5\end{array}$ & $\begin{array}{l}10,000 \\
12,100 \\
14,300 \\
16,400\end{array}$ & $\begin{array}{l}106 \\
131 \\
133 \\
137\end{array}$ & $\begin{array}{l}84 \\
76 \\
63 \\
57\end{array}$ \\
\hline$\underset{26}{\text { M.L. }}$ & $\begin{array}{c}\text { Control } \\
5.4 \\
12.5 \\
20.4\end{array}$ & $\begin{array}{l}0.37 \\
0.60 \\
2.39 \\
1.97\end{array}$ & $\begin{array}{c}97.0 \\
107 \\
105 \\
99.0\end{array}$ & $\begin{array}{l}459 \\
386 \\
318 \\
284\end{array}$ & $\begin{array}{l}21.2 \\
27.7 \\
32.0 \\
34.9\end{array}$ & $\begin{array}{r}8,250 \\
12,300 \\
15,800 \\
19,500\end{array}$ & $\begin{array}{r}98 \\
120 \\
127 \\
139\end{array}$ & $\begin{array}{l}69 \\
64 \\
63 \\
57\end{array}$ \\
\hline
\end{tabular}

* Clearance values are corrected to $1.73 \mathrm{~m}^{2}$ body surface area. See Methods section for abbreviations.

$\dagger$ All subjects are females.

$l$-Norepinephrine induced a mean increase in $\mathrm{RR}$ of 3,280 dynes-sec- $\mathrm{cm}^{-5}$ ( +68.5 per cent) in normotensive and of 4,740 dynes-sec- $\mathrm{cm}^{-5}(+50.3$ per cent) in hypertensive subjects. Similarly, epinephrine induced equal response in normotensive and hypertensive subjects, 1,460 dynes-sec- $\mathrm{cm}^{-5}$ $(+23.7$ per cent $)$ in the former and 2,530 dynessec- $\mathrm{cm}^{-5}(+33.9$ per cent) in the latter.

Regular diet with reduced salt content (Tables $I V-V I I)$. In four normotensive subjects salt restriction for periods of 17 to 45 days did not affect control values for $P_{m}, R P F$ or $R R$ in a sig- nificant or consistent manner. However, in some hypertensive subjects salt restriction for periods of 8 to 18 days did affect systemic and renal hemodynamics: systemic pressure decreased in three of eight, RPF decreased in six of eight, and RR increased in four of the eight hypertensive subjects.

Dietary salt restriction did not alter the response of $P_{m}$ to $l$-norepinephrine in the normotensive group: $P_{m}$ increased 27 per cent on salt restriction as compared with 21 per cent on regular salt intake in Patient A.B.; 29 as compared 
TABLE V

Effect of epinephrine on renal and systemic hemodynamics in normotensive and hypertensive subjects on reduced salt intake*

\begin{tabular}{|c|c|c|c|c|c|c|c|c|}
\hline $\begin{array}{l}\text { Subject† } \\
\text { Age }\end{array}$ & Epinephrine & $\begin{array}{l}\text { Urine } \\
\text { volume }\end{array}$ & GFR & RPF & FF & $\mathbf{R} \mathbf{R}$ & $P_{m}$ & Pulse \\
\hline yrs & $\begin{array}{c}\mu \mathrm{g} / \min / \\
1.73 \mathrm{~m}^{2}\end{array}$ & $m l / m i n$ & $\mathrm{ml} / \min$ & $m l / m i n$ & $\%$ & $\begin{array}{c}\text { dynes- } \\
\text { sec-cm-5 }\end{array}$ & $m m H g$ & $\mathrm{rate} / \mathrm{min}$ \\
\hline $\begin{array}{c}\text { A.B. } \\
19\end{array}$ & $\begin{array}{c}\text { Control } \\
4.7 \\
7.6 \\
14.0 \\
22.8\end{array}$ & $\begin{array}{l}4.23 \\
2.65 \\
4.75 \\
8.77 \\
8.05\end{array}$ & $\begin{array}{l}\text { Normo } \\
111 \\
112 \\
114 \\
108 \\
101\end{array}$ & $\begin{array}{c}\text { sive subj } \\
749 \\
607 \\
590 \\
498 \\
488\end{array}$ & $\begin{array}{l}15.0 \\
18.5 \\
19.4 \\
21.6 \\
20.8\end{array}$ & $\begin{array}{l}4,270 \\
4,760 \\
4,610 \\
5,540 \\
5,660\end{array}$ & $\begin{array}{l}83 \\
76 \\
72 \\
73 \\
73\end{array}$ & $\begin{array}{l}100 \\
131 \\
136 \\
141 \\
140\end{array}$ \\
\hline$\underset{45}{\text { M.So. }}$ & $\begin{array}{c}\text { Control } \\
3.2 \\
4.6 \\
7.6 \\
13.9 \\
22.6\end{array}$ & $\begin{array}{l}0.56 \\
0.51 \\
0.49 \\
0.43 \\
0.89 \\
2.01\end{array}$ & $\begin{array}{l}108 \\
102 \\
108 \\
110 \\
112 \\
117\end{array}$ & $\begin{array}{l}553 \\
488 \\
424 \\
408 \\
382 \\
360\end{array}$ & $\begin{array}{l}19.5 \\
20.9 \\
25.5 \\
27.0 \\
29.3 \\
32.5\end{array}$ & $\begin{array}{l}6,120 \\
6,560 \\
7,940 \\
8,810 \\
8,650 \\
9,670\end{array}$ & $\begin{array}{l}87 \\
83 \\
83 \\
84 \\
84 \\
88\end{array}$ & $\begin{array}{r}96 \\
101 \\
114 \\
118 \\
121 \\
126\end{array}$ \\
\hline $\begin{array}{c}\text { M.S. } \\
39\end{array}$ & $\begin{array}{c}\text { Control } \\
3.0 \\
4.4 \\
7.2 \\
13.1 \\
21.4\end{array}$ & $\begin{array}{l}0.70 \\
1.77 \\
5.47 \\
3.25 \\
3.02 \\
1.90\end{array}$ & $\begin{array}{l}118 \\
123 \\
128 \\
130 \\
135 \\
110\end{array}$ & $\begin{array}{l}500 \\
546 \\
506 \\
463 \\
447 \\
330\end{array}$ & $\begin{array}{l}23.6 \\
22.6 \\
25.3 \\
28.1 \\
30.2 \\
333\end{array}$ & $\begin{array}{r}6,240 \\
5,700 \\
5,900 \\
7,320 \\
7,180 \\
10,000\end{array}$ & $\begin{array}{l}81 \\
81 \\
78 \\
80 \\
83 \\
85\end{array}$ & $\begin{array}{l}104 \\
105 \\
104 \\
103 \\
108 \\
114\end{array}$ \\
\hline B.B. & $\begin{array}{c}\text { Control } \\
2.7 \\
4.1 \\
6.7 \\
12.4 \\
20.2\end{array}$ & $\begin{array}{l}0.95 \\
1.00 \\
1.18 \\
1.00 \\
0.82 \\
1.30\end{array}$ & $\begin{array}{l}78.4 \\
81.0 \\
80.9 \\
79.9 \\
82.0 \\
95.0\end{array}$ & $\begin{array}{l}524 \\
550 \\
445 \\
476 \\
445 \\
493\end{array}$ & $\begin{array}{l}15.0 \\
14.7 \\
18.2 \\
16.8 \\
18.4 \\
19.3\end{array}$ & $\begin{array}{l}6,670 \\
6,100 \\
7,750 \\
7,340 \\
7,220 \\
6,710\end{array}$ & $\begin{array}{l}85 \\
82 \\
84 \\
86 \\
79 \\
81\end{array}$ & $\begin{array}{r}88 \\
91 \\
96 \\
103 \\
108 \\
117\end{array}$ \\
\hline \multicolumn{9}{|c|}{ Hypertensive patients } \\
\hline $\begin{array}{c}\text { E.H. } \\
42\end{array}$ & $\begin{array}{c}\text { Control } \\
2.4 \\
6.1 \\
11.1 \\
18.2\end{array}$ & $\begin{array}{l}5.52 \\
6.38 \\
7.77 \\
7.82 \\
8.80\end{array}$ & $\begin{array}{l}77.2 \\
85.2 \\
91.4 \\
87.1 \\
96.0\end{array}$ & $\begin{array}{l}396 \\
431 \\
408 \\
378 \\
382\end{array}$ & $\begin{array}{l}19.5 \\
19.8 \\
22.4 \\
23.0 \\
25.1\end{array}$ & $\begin{array}{r}10,600 \\
10,100 \\
9,000 \\
9,610 \\
9,970\end{array}$ & $\begin{array}{r}106 \\
109 \\
94 \\
93 \\
97\end{array}$ & $\begin{array}{r}75 \\
74 \\
88 \\
94 \\
105\end{array}$ \\
\hline $\begin{array}{c}\text { M.L. } \\
26\end{array}$ & $\begin{array}{c}\text { Control } \\
3.5 \\
6.8 \\
12.5 \\
20.4\end{array}$ & $\begin{array}{l}0.36 \\
0.38 \\
0.49 \\
0.33 \\
0.69\end{array}$ & $\begin{array}{l}109 \\
115 \\
140 \\
120 \\
129\end{array}$ & $\begin{array}{l}431 \\
415 \\
457 \\
313 \\
299\end{array}$ & $\begin{array}{l}25.2 \\
27.6 \\
30.5 \\
38.3 \\
43.3\end{array}$ & $\begin{array}{r}8,550 \\
8,660 \\
8,050 \\
14,600 \\
14,700\end{array}$ & $\begin{array}{r}97 \\
94 \\
97 \\
118 \\
114\end{array}$ & $\begin{array}{r}73 \\
93 \\
101 \\
135 \\
133\end{array}$ \\
\hline$\underset{26}{\text { M.R. }}$ & $\begin{array}{c}\text { Control } \\
4.6 \\
15.0 \\
16.1 \\
23.0 \\
27.6\end{array}$ & $\begin{array}{l}8.70 \\
7.52 \\
4.82 \\
3.14 \\
1.72 \\
1.60\end{array}$ & $\begin{array}{l}146 \\
138 \\
129 \\
124 \\
135 \\
133\end{array}$ & $\begin{array}{l}695 \\
623 \\
460 \\
382 \\
376 \\
344\end{array}$ & $\begin{array}{l}21.2 \\
22.2 \\
28.1 \\
32.3 \\
35.9 \\
38.7\end{array}$ & $\begin{array}{r}4,670 \\
4,930 \\
6,770 \\
8,720 \\
8,850 \\
10,300\end{array}$ & $\begin{array}{l}85 \\
80 \\
81 \\
86 \\
86 \\
91\end{array}$ & $\begin{array}{r}91 \\
100 \\
109 \\
115 \\
118 \\
124\end{array}$ \\
\hline $\begin{array}{c}\text { N.F. } \\
39\end{array}$ & $\begin{array}{c}\text { Control } \\
3.9 \\
9.8 \\
13.7 \\
19.5\end{array}$ & $\begin{array}{l}4.30 \\
4.03 \\
3.72 \\
2.63 \\
1.30\end{array}$ & $\begin{array}{c}109 \\
123 \\
101 \\
102 \\
71.8\end{array}$ & $\begin{array}{l}579 \\
561 \\
389 \\
380 \\
255\end{array}$ & $\begin{array}{l}18.9 \\
21.9 \\
26.0 \\
26.8 \\
28.2\end{array}$ & $\begin{array}{r}6,210 \\
6,960 \\
10,600 \\
11,300 \\
15,800\end{array}$ & $\begin{array}{r}101 \\
99 \\
104 \\
108 \\
102\end{array}$ & $\begin{array}{r}92 \\
100 \\
113 \\
120 \\
125\end{array}$ \\
\hline $\begin{array}{l}\text { J.M. } \\
37\end{array}$ & $\begin{array}{c}\text { Control } \\
4.4 \\
10.9 \\
15.2\end{array}$ & $\begin{array}{l}0.53 \\
0.73 \\
0.77 \\
0.61\end{array}$ & $\begin{array}{c}102 \\
112 \\
87.9 \\
83.3\end{array}$ & $\begin{array}{l}411 \\
434 \\
320 \\
288\end{array}$ & $\begin{array}{l}24.8 \\
25.8 \\
27.4 \\
28.9\end{array}$ & $\begin{array}{r}10,000 \\
9,600 \\
13,200 \\
14,400\end{array}$ & $\begin{array}{l}104 \\
105 \\
106 \\
104\end{array}$ & $\begin{array}{r}88 \\
99 \\
114 \\
124\end{array}$ \\
\hline L.L. & $\begin{array}{c}\text { Control } \\
4.5 \\
11.4 \\
15.9\end{array}$ & $\begin{array}{l}3.16 \\
5.19 \\
2.44 \\
1.16\end{array}$ & $\begin{array}{c}95.9 \\
104 \\
91.2 \\
95.5\end{array}$ & $\begin{array}{l}659 \\
606 \\
498 \\
525\end{array}$ & $\begin{array}{l}14.5 \\
17.2 \\
18.3 \\
18.2\end{array}$ & $\begin{array}{l}6,450 \\
6,660 \\
7,300 \\
7,100\end{array}$ & $\begin{array}{r}107 \\
102 \\
93 \\
95\end{array}$ & $\begin{array}{r}98 \\
104 \\
120 \\
125\end{array}$ \\
\hline P.T. & $\begin{array}{c}\text { Control } \\
3.8 \\
9.6 \\
13.5\end{array}$ & $\begin{array}{l}0.40 \\
6.38 \\
8.54 \\
7.14\end{array}$ & $\begin{array}{l}108 \\
121 \\
107 \\
106\end{array}$ & $\begin{array}{l}496 \\
507 \\
416 \\
417\end{array}$ & $\begin{array}{l}22.7 \\
23.8 \\
25.7 \\
25.4\end{array}$ & $\begin{array}{l}9,000 \\
8,480 \\
9,800 \\
9,460\end{array}$ & $\begin{array}{l}112 \\
108 \\
103 \\
100\end{array}$ & $\begin{array}{r}82 \\
100 \\
109 \\
121\end{array}$ \\
\hline
\end{tabular}

* Clearance values are corrected to $1.73 \mathrm{~m}^{2}$ body surface area. See Methods section for abbreviations.

$\dagger$ J.M. is the only male subject. 
GOMBOS, HULET, BOPP, GOLDRING, BALDWIN AND CHASIS

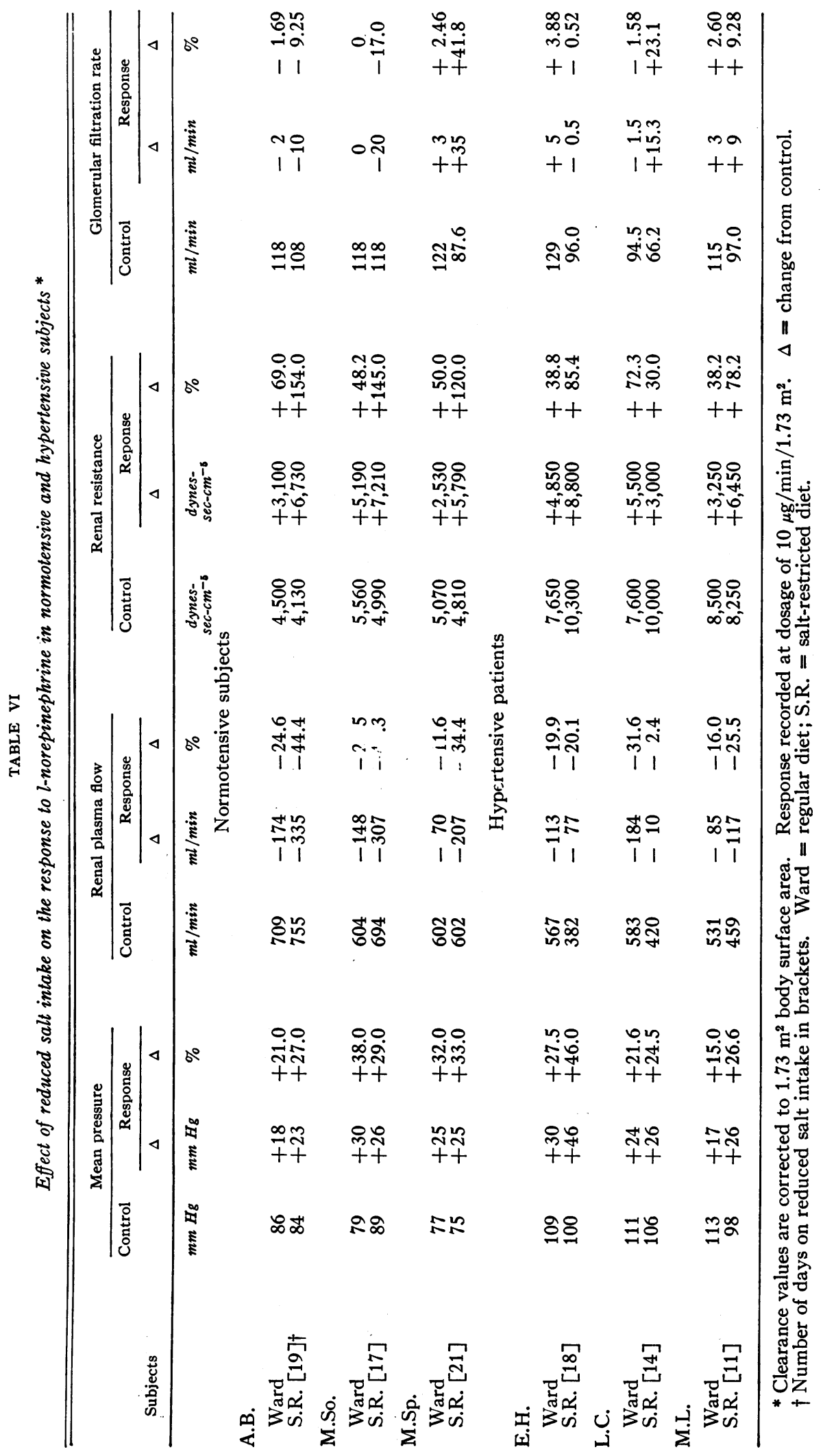




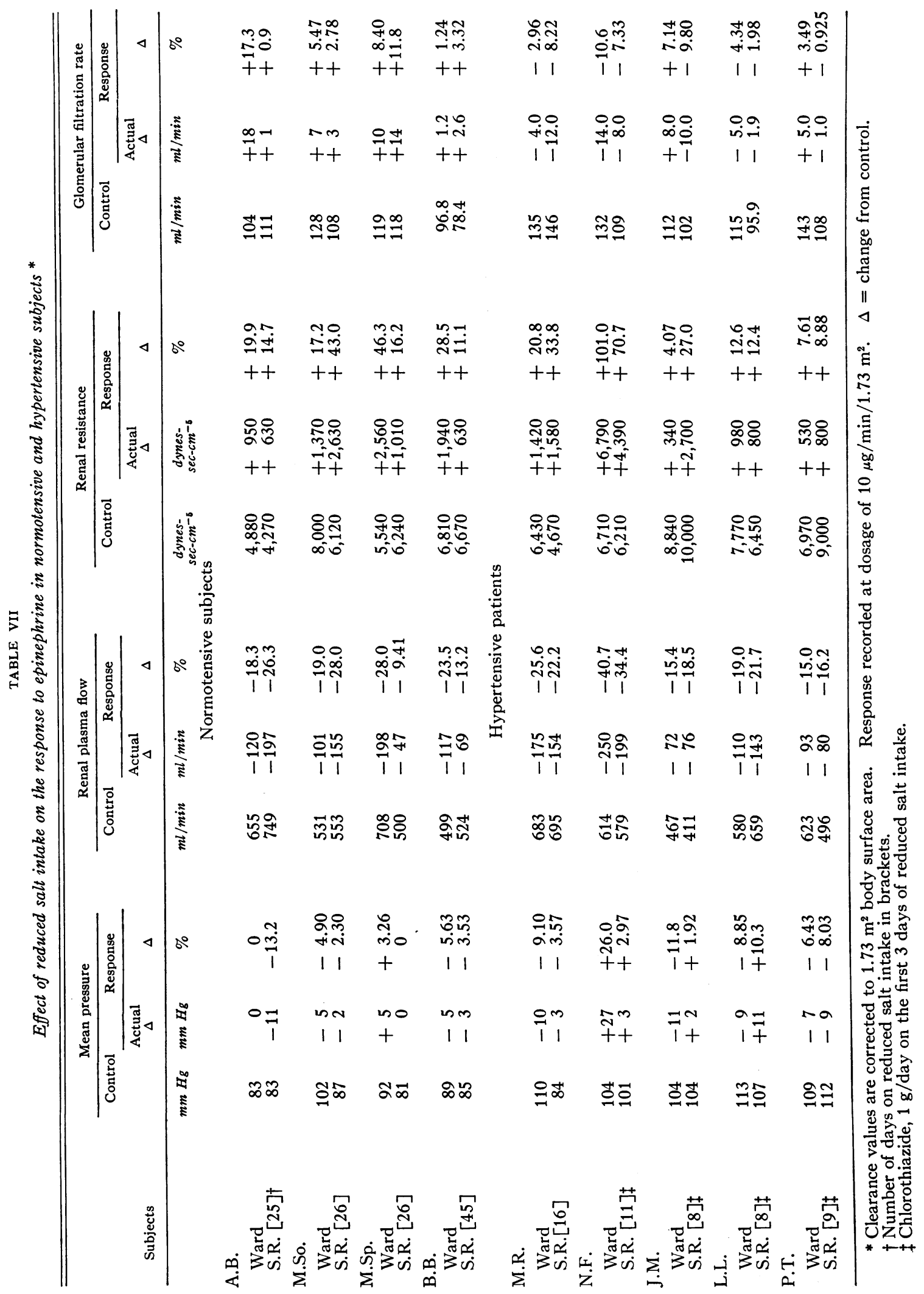


with 38 per cent in M.So.; and 33 as compared with 32 per cent in M.Sp. Salt restriction, however, increased $\mathrm{P}_{\mathrm{m}}$ responses to $l$-norepinephrine in two of three hypertensive patients, 46 per cent as compared with 27.5 per cent in Patient E.H., 26.6 as compared with 15.0 per cent in M.L., and 24.5 as compared with 21.6 per cent in L.C. Salt restriction did not affect the response in $\mathrm{P}_{\mathrm{m}}$ to epinephrine in either normotensive or hypertensive subjects.

Salt restriction exaggerated the response of $\mathrm{RPF}$ to $l$-norepinephrine in normotensive subjects : RPF decreased 44.4 per cent as compared with 24.6 per cent on regular salt intake in $\mathrm{Pa}$ tient A.B.; 44.3 as compared with 24.5 per cent in M.So.; and 34.4 as compared with 11.6 per cent in M.Sp. Salt restriction had no consistent effect on response of RPF to $l$-norepinephrine in hypertensive subjects. The response of RPF to epinephrine was not affected by sodium restriction in either normotensive or hypertensive subjects.

Salt restriction exaggerated the effect of $l$-norepinephrine on $R R$ in normotensive subjects. $\mathrm{RR}$ increased 154 per cent on sodium restriction as compared with 69 per cent on regular salt intake in Patient A.B., 145 as compared with 48.2 per cent in M.So., and 120 as compared with 50 per cent in M.Sp. In two of the three hypertensive patients, salt restriction increased the effect of $l$-norepinephrine on $\mathrm{RR}$; this increased response in $R R$ resulted from greater increase in $\mathrm{P}_{\mathrm{m}}$ rather than from decrease in RPF. Salt restriction had no consistent effect on the response of $R R$ to epinephrine in either normotensive or hypertensive subjects.

\section{DISCUSSION}

Our data demonstrate that the renal vasoconstrictor response to $l$-norepinephrine and epinephrine, measured as per cent change in renal resistance, is the same in normotensive and hypertensive subjects. Comparison of arteriolar reactivity in normotensive and hypertensive subjects necessitates interpreting changes produced in the resistance of arterioles that differ in initial circumference and initial degree of vasoconstriction, and that differ structurally as regards smooth muscle mass and sclerosis.
A given decrease in vessel circumference will result in a greater decrease in cross-sectional area (or increase in resistance) in a smaller (hypertensive) vessel than in a larger (normotensive) one. This disproportionate effect on renal resistance of given amounts of arteriolar muscle shortening may best be taken into account by comparing percentage rather than absolute changes in renal resistance. The proportional increases in renal resistance observed in the two groups in response to $l$-norepinephrine and epinephrine indicate that the actual circumference of the renal arterioles decreased to a greater extent in normotensive subjects, despite the fact that the absolute increase in renal resistance was greater in hypertensive patients.

The percentile method of comparison also takes into account the fact that the initial degree of preexisting vasoconstriction affects arteriolar reactivity; i.e., a less constricted vessel would be expected to respond by greater shortening than the more constricted vessel. Although Folkow and Öberg (26) reported that percentage increase in flow resistance in the hind limb of a cat is less in constricted vessels than in normal or dilated ones in response to norepinephrine or angiotensin, we doubt that data obtained in anesthetized cats, in which variations in initial vascular tone were induced by bilateral carotid artery occlusion or vagal stimulation, can be used to interpret relative reactivity in normotensive and hypertensive man.

The muscle mass of the renal vasculature might also affect comparison of reactivity to vasoconstrictor agents. It would seem reasonable to expect that a vessel with hypertrophied muscle fibers would respond with greater constriction even though reactivity of individual muscle fibers was not greater than normal. The failure of hypertensive patients to respond to a greater extent than do normotensive subjects, despite the presence of muscular hypertrophy in the former, supports the interpretation that reactivity to $l$-norepinephrine and epinephrine is not increased in hypertension.

The increased initial renal resistance in hypertensive subjects may be attributed to functional arteriolar constriction, anatomical narrowing, or both. Sclerotic changes in the vessel wall might 
decrease contractility and in this way interfere with the action of a vasoconstrictor agent. However, our studies are not significantly affected by such changes in the vessel wall, since patients were selected early in the course of hypertensive disease (as judged by history, clinical data, and the presence of only minimal reductions in RPF), indicating that functional vasoconstriction was predominantly responsible for the increased renal resistance.

A maximal limit to vasoconstriction in hypertensive patients might limit reactivity and in this way affect the comparison with normotensive subjects. The similarity of the curves for percentage change in renal resistance (Figures 4 and 5) throughout the dosage range of vasoconstrictors administered demonstrates that comparison of reactivity in normotensive and hypertensive subjects is not affected by such a ceiling.

Renal arteriolar reactivity to vasoconstrictor stimuli would be more profitably studied by employing an agent whose action is limited to the renal vascular bed. $l$-Norepinephrine increased systemic resistance and pressure in addition to its direct effect on the renal circulation and these systemic changes of themselves may induce renal vasoconstriction. However, unless the effect on the renal circulation of comparable changes in systemic pressure differs in normotensive and hypertensive subjects, the possible influence of systemic pressure on renal resistance should not limit the comparison of renal arteriolar reactivity in the two groups. Epinephrine did not affect mean systemic pressure, and here the changes in renal resistance may be interpreted unequivocally as reflecting the direct effect of the vasoconstrictor agent on the renal vessels.

Assuming that cardiac output is affected similarly in the hypertensive and normotensive subjects by both epinephrine and $l$-norepinephrine, as has been reported by Goldenberg and associates (8), our observations indicate that the reactivity of the systemic vessels to epinephrine and $l$-norepinephrine is the same in normotensive and hypertensive subjects, since relative changes in systemic pressure were equal in both groups. The observation that reactivity of the systemic arterioles is comparable in normotensive and hypertensive subjects does not support the thesis that essential hypertension is related to increased vascular sensitivity to circulating norepinephrine.

Confirming the observations of others (27-29), sodium restriction for periods ranging from 1 to 4 weeks produced a decrease in both systemic pressure and renal plasma flow in hypertensive patients; these did not decrease in the normotensive subjects. Sodium restriction causes reduction in extracellular fluid and plasma volumes $(28,30$ $32)$, and in cardiac output $(31,32)$. These hemodynamic effects could account for the decreases in systemic pressure and renal plasma flow observed in the hypertensive patients. Decrease of renal plasma flow in hypertensive patients indicates that greater renal vasoconstriction occurred in the hypertensive than in the normotensive subjects, and may be explained by a difference in renal response to systemic changes induced by sodium restriction or may indicate that greater reductions in extracellular fluid volume and cardiac output occurred in hypertensive subjects. Our observation that sodium restriction produced greater weight loss in hypertensive than in normotensive subjects supports the latter possibility.

Restriction of sodium intake failed to decrease renal arteriolar reactivity to $l$-norepinephrine or epinephrine in both normotensive and hypertensive subjects. In fact, the response to $l$-norepinephrine was enhanced in both groups, the effect being relatively greater in normotensive than in hypertensive subjects. This enhanced renal vasoconstrictor response is unexplained, but may reflect differences in smooth muscle contractility associated with changes in sodium content or increased sensitivity to vasoconstrictor influences resulting from reduced circulating blood volume. Tobian and Fox (33) have reported that there is a gain of sodium and a loss of potassium in the arterial wall in dogs during norepinephrine infusion and have suggested that these electrolyte shifts play a part in smooth muscle contractility. Friedman, Jamieson and Friedman (34) have demonstrated that smooth muscle tone and responsiveness to drug-induced contraction are enhanced in the rat when the ratio of extracellular to intracellular sodium concentration is reduced. The applicability of these observations to our results cannot be assessed inasmuch as we have no data relative to the effect of sodium restriction on the 
sodium gradient across the vessel wall in our patients. The fact that the reactivity of the renal circulation to $l$-norepinephrine was increased to a greater extent in normotensive than in hypertensive subjects during sodium restriction may be attributed to the initially greater vasoconstriction which had already been produced by sodium restriction in the latter.

\section{CONCLUSIONS}

1. Renal and systemic arteriolar vasoconstrictor reactivity is equal in normotensive and hypertensive subjects, as shown by equal relative increases in both renal resistance and systemic blood pressure in response to the administration of $l$-norepinephrine and epinephrine. This observation is contrary to the thesis that essential hypertension is related to increased vascular sensitivity to circulating norepinephrine.

2. Restricted sodium intake fails to decrease renal arteriolar vasoconstrictor reactivity to $l$-norepinephrine and epinephrine in either normotensive or hypertensive subjects.

\section{REFERENCES}

1. Kylin, E. Über Hypertonie und Nierenkrankheit. Zbl. inn. Med. 1921, 42, 441.

2. Brems, A. Uber die perorale Adrenalinblutdruckwirkung. Acta med. scand. 1926, 64, 69.

3. Gordon, W., and Levitt, G. Blood pressure changes in normals and in hypertensives after intravenous epinephrine and histamine. J. clin. Invest. 1935, 14, 367.

4. Fatherree, T. J., and Hines, E. A., Jr. The blood pressure response to epinephrine administered intravenously to subjects with normal blood pressure and to patients with essential hypertension. Amer. Heart J. 1938, 16, 66.

5. Judson, W. E., Culbertson, J. W., Tinsley, C. M., Litter, J., and Wilkins, R. W. The comparative effects of small intravenous doses of epinephrine upon arterial pressure and pulse rate in normotensive subjects and in hypertensive patients before and after thoracolumbar sympathectomy. J. clin. Invest. 1950, 29, 1405.

6. Judson, W. E., Epstein, F. H., and Wilkins, R. W. The comparative effect of small intravenous doses of $l$-norepinephrine upon arterial pressure and pulse rate in normotensive subjects and hypertensive patients before and after thoracolumbar sympathectomy. J. clin. Invest. 1950, 29, 1414.

7. Barany, F. R., and James, P. The sensitivity to $l$-noradrenalin of patients with high blood pressure. Clin. Sci. 1959, 18, 543.
8. Goldenberg, M., Pines, K. L., Baldwin, E. de F., Greene, D. G., and Roh, C. E. The hemodynamic response of man to nor-epinephrine and epinephrine and its relation to the problem of hypertension. Amer. J. Med. 1948, 5, 792.

9. Clough, P. W. A study of the cardiovascular reaction to epinephrin. Epinephrin sensitiveness in patients with hypertension. Bull. Johns Hopk. Hosp. 1920, 31, 266.

10. Jensen, J. The adrenalin test in hypertension. Amer. Heart J. 1930, 5, 763.

11. Doyle, A. E., and Black, H. Reactivity to pressor agents in hypertension. Circulation 1955, 12, 974.

12. Pickering, G. W., and Kissin, M. The effects of adrenaline and of cold on the blood pressure in human hypertension. Clin. Sci. 1936, 2, 201.

13. Prinzmetal, M., and Wilson, C. The nature of the peripheral resistance in arterial hypertension with special reference to the vasomotor system. J. clin. Invest. 1936, 15, 63.

14. Mendlowitz, M., and Naftchi, N. Work of digital vasoconstriction produced by infused norepinephrine in primary hypertension. J. appl. Physiol. 1958, $13,247$.

15. Doyle, A. E., Fraser, J. R., and Marshall, R. J. Reactivity of forearm vessels to vasoconstrictor substances in hypertensive and normotensive subjects. Clin. Sci. 1959, 18, 441.

16. Duff, R. S. Adrenaline sensivity of peripheral blood vessels in human hypertension. Brit. Heart J. 1957, 19, 45.

17. Greisman, S. E. The reaction of the capillary bed of the nailfold to the continuous intravenous infusion of levo-nor-epinephrine in patients with normal blood pressure and with essential hypertension. J. clin. Invest. 1954, 33, 975.

18. Chasis, H., Ranges, H. A., Goldring, W., and Smith, H. W. The control of renal blood flow and glomerular filtration in normal man. J. clin. Invest. 1938, 17, 683.

19. Smythe, C. McC., Nickel, J. F., and Bradley, S. E. The effect of epinephrine (USP), $l$-epinephrine and $l$-norepinephrine on glomerular filtration rate, renal plasma flow, and the urinary excretion of sodium, potassium, and water in normal man. J. clin. Invest. 1952, 31, 499.

20. Pullman, T. N., and McClure, W. W. The response of the renal circulation in man to constant-speed infusion of $l$-norepinephrine. Circulation 1954, 9, 600.

21. Raab, W., Humphreys, R. J., Makous, N., DeGrandpré, R., and Gigee, W. Pressor effects of epinephrine, norepinephrine and desoxycorticosterone acetate (DCA) weakened by sodium withdrawal. Circulation 1952, 6, 373.

22. Aleksandrow, D., Wysznacka, W., and Gajewski, J. Influence of chlorothiazide upon arterial responsiveness to nor-epinephrine in hypertensive subjects. New Engl. J. Med. 1959, 261, 1052. 
23. Dahl, L. K. Pressor effects of norepinephrine after drastic reduction of sodium intake. Circulation 1957, 15, 231.

24. Gomez, D. M. L'hémodynamique de la circulation renalé. Rev. Sci. 1947, 85, 451.

25. Smith, H. W. Principles of Renal Physiology. New York, Oxford Univ. Press, 1956.

26. Folkow, B., and Öberg, B. The effect of functionally induced changes in wall/lumen ratio on the vasoconstrictor response to standard amounts of vasoactive agents. Acta physiol. scand. 1959, 47, 131.

27. Chasis, H., Goldring, W., Breed, E. S., Schreiner, G. E., and Bolomey, A. A. Salt and protein restriction-Effects on blood pressure and renal hemodynamics in hypertensive patients. J. Amer. med. Ass. 1950, 142, 711.

28. Weston, R. E., Hellman, L., Escher, D. J. W., Edelman, I. S., Grossman, J., and Leiter, L. Studies on the influence of the low sodium cardiac diet and the Kempner regimen on renal hemodynamics and electrolyte excretion in hypertensive subjects. J. clin. Invest. 1950, 29, 639.
29. Corcoran, A. C., Taylor, R. D., and Page, I. H. Controlled observations on the effect of low sodium dietotherapy in essential hypertension. Circulation $1951,3,1$.

30. McCance, R. A. The effect of salt deficiency in man on the volume of the extracellular fluids, and on the composition of sweat, saliva, gastric juice and cerebrospinal fluid. J. Physiol. (Lond.) 1938, 92, 208.

31. Dustan, H. P., Cumming, G. R., Corcoran, A. C., and Page, I. H. A mechanism of chlorothiazideenhanced effectiveness of antihypertensive ganglioplegic drugs. Circulation 1959, 19, 360.

32. Frohlich, E. D., Schnaper, H. W., Wilson, I. M., and Freis, E. D. Hemodynamic alterations in hypertensive patients due to chlorothiazide. New Engl. J. Med. 1960, 262, 1261.

33. Tobian, L., and Fox, A. The effect of nor-epinephrine on the electrolyte composition of arterial smooth muscle. J. clin. Invest. 1956, 35, 297.

34. Friedman, S. M., Jamieson, J. D., and Friedman, C. L. Sodium gradient, smooth muscle tone, and blood pressure regulation. Circulat. Res. 1959, 7, 44.

\section{ANNOUNCEMENT OF MEETINGS}

The Nineteenth Annual Meeting of THE AMERICAN FEDERATION FOR CLINICAL RESEARCH will be held in Atlantic City, N. J., on Sunday, April 29, 1962 at 9:00 a.m. at the Casino Theatre on the Steel Pier. On Sunday afternoon, April 29, 1962, joint sectional meetings with The American Society for Clinical Investigation will be held in rooms in Chalfonte-Haddon Hall; and on Sunday evening, additional meetings will be held under the auspices of The American Federation for Clinical Research, in Chalfonte-Haddon Hall.

The Fifty-fourth Annual Meeting of THE AMERICAN SOCIETY FOR CLINICAL INVESTIGATION, INC., will be held in Atlantic City, N. J., on Sunday afternoon, April 29, 1962, in Chalfonte-Haddon Hall in simultaneous programs sponsored in conjunction with The American Federation for Clinical Research; and on Monday, April 30, at 9:00 a.m. at the Casino Theatre on the Steel Pier.

THE ASSOCIATION OF AMERICAN PHYSICIANS will hold its Seventy-fifth Annual Meeting at Atlantic City, N. J., at the Casino Theatre on the Steel Pier on Tuesday, May 1, 1962, at 9:30 a.m., and in the Vernon Room, Chalfonte-Haddon Hall on Wednesday, May 2, 1962, at 9:30 a.m. 